\title{
The Influence of Leadership and Motivation on Employee Performance at the South Tangerang Fire and Rescue Service
}

\author{
Laila Irawati \\ Pamulang University, Indonesia \\ Email: dosen02205@unpam.ac.id
}

(Received: December 12-2019; revised: April 15-2020; published: June 31-2020)

\begin{abstract}
Human resources (HR) is one of the key factors in economic reform, namely how to create quality human resources who have skills and highly competitive in global competition. Humans always develop actively and dominantly in every organization's activities, because humans become planners, actors, and determinants of the realization of organizational goals. This study aims to determine the effect of leadership and motivation on employee performance at the South Tangerang Fire and Rescue Service. The method used was explanatory research with a sample of 55 respondents. The analysis technique uses statistical analysis with regression testing, correlation, determination, and hypothesis testing. The results of this study leadership have a significant effect on employee performance by $48.9 \%$, the hypothesis test obtained significance $0,000<0.05$. Motivation has a significant effect on employee performance by $34.8 \%$, hypothesis testing obtained significance $0,000<0.05$. Simultaneous leadership and motivation significantly influence employee performance by $56.8 \%$, hypothesis testing obtained significance 0,000 $<0.05$.
\end{abstract}

Keywords: Leadership; motivation; employee performance

\section{INTRODUCTION}

Human resources (HR) is one of the key factors in economic reform (Gaines \& Kappeler, 2011; Masini, 1990; Sinambela, 2016; Spivack \& Woodside, 2019). Creating high-quality human resources who have skills and highly competitive in global competition. Humans always develop actively and dominantly in every organization's activities, because humans become planners, actors, and determinants of the realization of organizational goals (Córdova, Durán, Pincheira, Palominos, \& Galindo, 2019; Cui, Zhang, Guo, Hu, \& Meng, 2019; Sharafoddin \& Emsia, 2016). Objectives are not possible without the active role of employees even though the tools used are sophisticated. Sophisticated tools that are owned are of no use if the active role of employees is not included (Bircan \& Gençler, 2015; Boer \& Blaga, 2012; Sze, Bluth, Bender, \& Parikh, 2017).

In a government organization, success or failure in carrying out the duties and administration of government is influenced by leadership (Akib, 2008; Akib \& Salam, 2016; Niswaty, Juniati, Darwis, Salam, \& Arhas, 2019). Through leadership and supported by an adequate capacity of government organizations, the implementation of good governance (Good Government) will be realized, on the contrary, the weakness of leadership is one of the causes of the collapse of bureaucratic performance in Indonesia.

Leadership (leadership) can be said as a way of a leader (leader) in directing, encouraging, and managing all the elements in the group or organization to achieve desired organizational 
120 Jurnal Administrare: Jurnal Pemikiran Ilmiah dan Pendidikan Administrasi Perkantoran

Vol. 7, No. 1, January - June 2020, Pages 119-128

goals so as to produce maximum employee performance. Increasing employee performance means achieving one's work in achieving goals. (Çetin, Karabay, \& Efe, 2012; Davila \& Elvira, 2012; Huertas-Valdivia, Gallego-Burín, \& Lloréns-Montes, 2019).

Relating to human resources which are the main tools for the smooth functioning of an organization can develop well if the workforce in the organization can develop properly if the workforce in the organization is given motivation related to the growth and development of one's nature because motivation is a part of encouraging employees to work according to the goals set too late.

Motivation is a factor that drives someone to do a certain activity, therefore motivation is often interpreted as a factor driving a person's behavior (Edy, 2009). Providing stimuli that can generate enthusiasm and drive work as optimal as possible so that someone wants to work together, work effectively, and be integrated with all their efforts to achieve organizational goals and satisfy individual needs. The size of the influence of work motivation depends on how much intensity of motivation is given, through the responsibility of doing work, the achievements achieved, self-development, and independence in acting.

Organizational performance is the answer to the success or failure of organizational goals that have been set (Akdol \& Arikboga, 2015; Karatepe, 2013; Suganthi, 2019). Company leaders or managers often ignore and do not pay attention to performance issues unless it is very bad, too often do not know how bad performance has fallen so that the company or agency faces a serious crisis (Dumitriu, Timofti, Nechita, \& Dumitriu, 2014; Malik, Dhar, \& Handa, 2016).

Performance must be done effectively and efficiently, which means that in carrying out the work of an organization using the resources of the organization it must be done carefully and thoroughly so that no waste occurs. Good and quality performance can have a good effect not only on the company or agency but on the employees or employees of the company itself, even can be felt by the wider community.

According to (Moeheriono, 2018), performance is a picture of the level of achievement of the implementation of a program of activities or policies in realizing the goals, objectives, vision, and mission of the organization as outlined through strategic planning or an organization.

The importance of the performance of Fire and Rescue Service employees is the process used to provide good work benefits if done correctly, and measure the extent of the performance of Fire and Rescue Service employees, this provides important benefits for employees and leaders in an organization, and the results of performance evaluations can be carried out to determine the right course of action. And the importance of employee performance needs to be examined to determine the ability of employees, acceptance of employee goals, the level of goals achieved, and the interaction between the goals and abilities of employees in the company where each of these elements affects a person's performance.

\section{METHOD}

The type of research used is associative, where the aim is to find out the search for interconnection. The population in this study amounted to 55 respondents from the South Tangerang Fire and Rescue Service. The sampling technique in this study is saturated sampling, where all members of the population are sampled. Thus the sample in this study amounted to 55 
respondents. In analyzing the data used the instrument test, classical assumption test, regression, coefficient of determination, and hypothesis testing.

\section{RESULT AND DISCUSSION}

Before conducting inferential statistical tests, it is the first known descriptive statistical analysis. This test is used to determine the minimum and maximum scores, mean scores, and standard deviations of each variable. The results are as follows:

Table 1.

Descriptive Analysis Results

\section{Descriptive Statistics}

\begin{tabular}{lr|r|r|r|r}
\hline & N & Minimum & Maximum & Mean & Std. Deviation \\
\hline$($ X1) & 55 & 31 & 48 & 38.44 & 4.417 \\
\hline$($ X2) & 55 & 31 & 48 & 38.31 & 3.844 \\
\hline$($ Y) & 55 & 33 & 46 & 39.24 & 3.600 \\
\hline Valid N (listwise) & 55 & & & & \\
\hline
\end{tabular}

Leadership obtained a minimum variance of 31 and a maximum variance of 48 with a mean score of 3.84 with a standard deviation of 4.417. Motivation obtained a minimum variance of 31 and a maximum variance of 48 with a mean score of 3.83 with a standard deviation of 3.844. Employee performance obtained a minimum variance of 33 and a maximum variance of 46 with a mean score of 3.92 with a standard deviation of 3,600 .

\section{The Influence of Leadership on Employee Performance}

Correlation coefficient analysis is intended to determine the level of relationship strength of the leadership variable on employee performance variables. The test results are as follows:

\section{Table 2.}

\section{Leadership Correlation Coefficient Test Results on Employee Performance}

Correlations $^{\text {b }}$

\begin{tabular}{llr|r}
\hline & & $(\mathrm{X} 1)$ & $(\mathrm{Y})$ \\
\hline (X1) & Pearson Correlation & 1 & $.699^{* *}$ \\
\cline { 2 - 4 } & Sig. (2-tailed) & & .000 \\
\hline (Y) & Pearson Correlation & $.699^{* *}$ & 1 \\
\cline { 2 - 4 } & Sig. (2-tailed) & .000 & \\
\hline
\end{tabular}

**. Correlation is significant at the 0.01 level (2-tailed).

b. Listwise $\mathrm{N}=55$

Analysis of the coefficient of determination is intended to determine the percentage of the influence of leadership variables on employee performance variables. The test results are as follows: 
122 Jurnal Administrare: Jurnal Pemikiran Ilmiah dan Pendidikan Administrasi Perkantoran Vol. 7, No. 1, January - June 2020, Pages 119-128

Table 3.

Leadership Coefficient Determination Test Results on Employee Performance Model Summary

\begin{tabular}{|c|c|c|c|c|}
\hline Model & $\mathrm{R}$ & R Square & $\begin{array}{c}\text { Adjusted R } \\
\text { Square }\end{array}$ & $\begin{array}{l}\text { Std. Error of the } \\
\text { Estimate }\end{array}$ \\
\hline 1 & $.699^{\mathrm{a}}$ & .489 & .479 & 2.598 \\
\hline
\end{tabular}

a. Predictors: (Constant), (X1)

Based on the test results obtained a determination value of 0.489 means that leadership has an influence contribution of $48.9 \%$ on employee performance.

Hypothesis testing with a t-test is used to find out which partial hypotheses are accepted. First Hypothesis: there is a significant influence between leadership on employee performance.

Table 4.

Leadership Hypothesis Test Results on Employee Performance

Coefficients $^{\mathrm{a}}$

Unstandardized $\quad$ Standardized

Coefficients Coefficients

\begin{tabular}{|c|c|c|c|c|c|}
\hline Model & $\mathrm{B}$ & Std. Error & Beta & $\mathrm{t}$ & Sig. \\
\hline (Constant) & 17.334 & 3.097 & & 5.597 & .000 \\
\hline (X1) & .570 & .080 & .699 & 7.118 & .000 \\
\hline
\end{tabular}

a. Dependent Variable: (Y)

Based on the test results in the above table, the value of $t$ count $>t$ table or $(7.118>2.006)$ is obtained, thus the first hypothesis proposed that there is a significant influence between leadership on employee performance is accepted. Based on the test results obtained a correlation value of 0.699 means that leadership has a strong relationship with employee performance.

\section{The Influence of Motivation on Employee Performance}

Correlation coefficient analysis is intended to determine the level of strength of the relationship of motivation variables on employee performance variables. The test results are as follows:

Table 5.

Motivation Correlation Coefficient Test Results on Employee Performance

Correlations $^{\text {b }}$

\begin{tabular}{llr|r}
\hline & & (X2) & \multicolumn{1}{c}{ (Y) } \\
\hline (X2) & Pearson Correlation & 1 & $.590^{* *}$ \\
\cline { 2 - 4 } & Sig. (2-tailed) & & .000 \\
\hline (Y) & Pearson Correlation & $.590^{* * *}$ & 1 \\
\cline { 2 - 4 } & Sig. (2-tailed) & .000 & \\
\hline
\end{tabular}

**. Correlation is significant at the 0.01 level (2-tailed).

b. Listwise $\mathrm{N}=55$ 
Based on the test results obtained a correlation value of 0.590 means that motivation has a moderate relationship to employee performance.

The coefficient of determination analysis is intended to find out the percentage of the influence of the motivational variables on employee performance variables. The test results are as follows

Table 6.

Motivation Determination Test Results for Employee Performance Model Summary

\begin{tabular}{lrr|rrr}
\hline Model & & \multicolumn{2}{c|}{$\begin{array}{c}\text { Adjusted R } \\
\text { Square }\end{array}$} & \multicolumn{2}{c}{$\begin{array}{c}\text { Std. Error of the } \\
\text { Estimate }\end{array}$} \\
\hline 1 & $\mathrm{R}$ & R Square & .348 & .336 & 2.934 \\
\hline
\end{tabular}

a. Predictors: (Constant), (X2)

Based on the test results obtained a determination value of 0.348 means that motivation has a contribution of $34.8 \%$ of the effect on employee performance.

Hypothesis testing with a t-test is used to find out which partial hypotheses are accepted. The second hypothesis: there is a significant influence between motivation on employee performance.

Table 7.

Motivation Hypothesis Test Results on Employee Performance

Coefficients $^{\mathrm{a}}$

\begin{tabular}{|c|c|c|c|c|c|c|}
\hline \multirow{2}{*}{\multicolumn{2}{|c|}{ Model }} & \multicolumn{2}{|c|}{$\begin{array}{l}\text { Unstandardized } \\
\text { Coefficients }\end{array}$} & \multirow{2}{*}{$\begin{array}{c}\text { Standardized } \\
\text { Coefficients } \\
\text { Beta }\end{array}$} & \multirow[b]{2}{*}{$\mathrm{t}$} & \multirow[b]{2}{*}{ Sig. } \\
\hline & & B & Std. Error & & & \\
\hline & (Constant) & 18.060 & 3.999 & & 4.516 & .000 \\
\hline & $(\mathrm{X} 2)$ & .553 & .104 & .590 & 5.322 & .000 \\
\hline
\end{tabular}

a. Dependent Variable: (Y)

Based on the test results in the above table, the value of $t$ count $>t$ table or $(5.322>2.006)$ is obtained, thus the second hypothesis proposed that there is a significant influence between motivation on employee performance is accepted.

\section{The Influence of Leadership and Motivation on Employee Performance}

This regression test is intended to determine changes in the dependent variable if the independent variable changes. The test results are as follows: 
124 Jurnal Administrare: Jurnal Pemikiran Ilmiah dan Pendidikan Administrasi Perkantoran Vol. 7, No. 1, January - June 2020, Pages 119-128

Table 8.

Multiple Linear Regression Testing Results

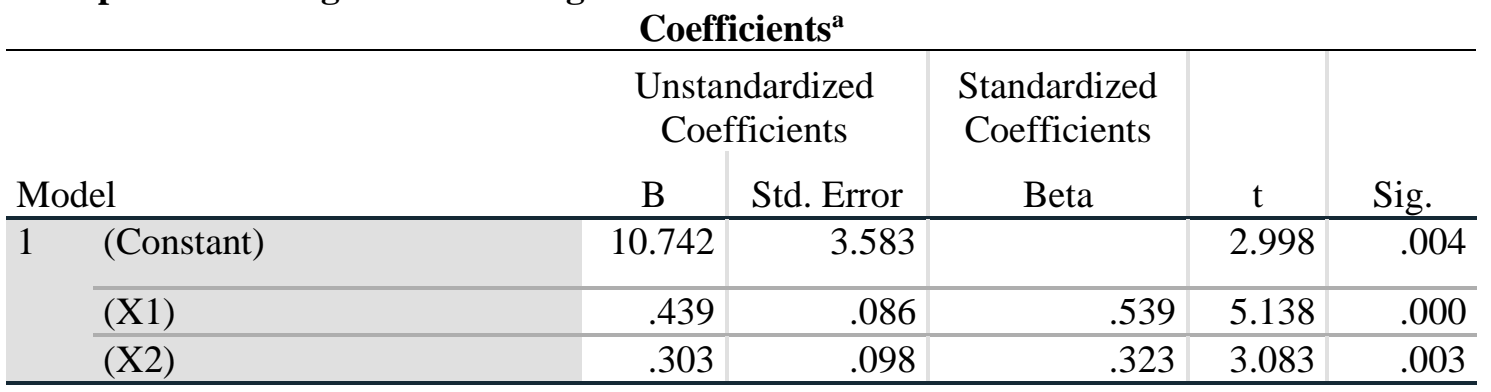

a. Dependent Variable: (Y)

Based on the test results in the above table, the regression equation $\mathrm{Y}=10.742+0.439 \mathrm{X} 1$ $+0.303 \mathrm{X} 2$ is obtained. From this equation explained that a constant of 10.742 means that if there is no leadership and motivation, then there is an employee performance value of 10.742 points. The leadership regression coefficient of 0.439 , this number is positive meaning that every time there is an increase in leadership by 0.439 , employee performance will also increase by 0.439 points. The regression coefficient of motivation is 0.303 , this number is positive, meaning that every time there is an increase in motivation by 0.303 , employee performance will also increase by 0.303 points.

Correlation coefficient analysis is intended to determine the level of relationship strength of the leadership and motivation variables on employee performance variables. The test results are as follows:

Table 9.

Simultaneous Correlation Results of Leadership and Motivation Coefficients on Employee Performance

Model Summary

\begin{tabular}{lrr|rr|r}
\hline Model & $\mathrm{R}$ & \multicolumn{2}{c|}{$\begin{array}{c}\text { Adjusted R } \\
\text { Square }\end{array}$} & $\begin{array}{c}\text { Std. Error of the } \\
\text { Estimate }\end{array}$ \\
\hline 1 & $.753^{\mathrm{a}}$ & .568 & .551 & 2.412 \\
\hline
\end{tabular}

a. Predictors: (Constant), (X2), (X1)

Based on the test results obtained a correlation value of 0.753 means that leadership and motivation simultaneously have a strong relationship to employee performance.

The coefficient of determination analysis is intended to find out the percentage of the influence of the leadership and motivation variables on employee performance variables. Based on the test results obtained a determination value of 0.568 means that leadership and motivation simultaneously have an influence contribution of $56.8 \%$ on employee performance, while the remaining $43.2 \%$ is influenced by other factors.

Hypothesis testing with the $\mathrm{F}$ test is used to find out which simultaneous hypotheses are accepted. Third hypothesis: there is a significant influence between leadership and motivation on employee performance. 
Table 10.

Leadership Hypothesis Test Results and Motivation of Employee Performance

\begin{tabular}{llr|r|r|c|c}
\multicolumn{7}{c}{ ANOVA $^{\mathbf{a}}$} \\
\hline \multicolumn{1}{l}{ Model } & Sum of Squares & \multicolumn{1}{c}{ df } & Mean Square & \multicolumn{1}{c}{ F } & \multicolumn{1}{c}{ Sig. } \\
\hline 1 & Regression & 397.377 & 2 & 198.689 & 34.149 & $.000^{\mathrm{b}}$ \\
\cline { 2 - 7 } & Residual & 302.550 & 52 & 5.818 & \\
\cline { 2 - 7 } & Total & 699.927 & 54 & & & \\
\hline
\end{tabular}

a. Dependent Variable: (Y)

b. Predictors: (Constant), (X2), (X1)

Based on the test results in the table above, obtained the value of $\mathrm{F}$ count $>\mathrm{F}$ table or $(34,149>2,790)$, thus the third hypothesis proposed that there is a significant influence between leadership and motivation on employee performance is accepted.

\section{Discussion}

\section{The Influence of Leadership on Employee Performance}

Leadership has a significant effect on employee performance with a correlation of 0.699 or has a strong relationship with an influential contribution of $48.9 \%$. Hypothesis testing obtained $t$ count $>t$ table or $(7.118>2.006)$. Thus the first hypothesis proposed that there is a significant effect between leadership on employee performance is accepted.

\section{The Influence of Motivation on Employee Performance}

Motivation has a significant effect on employee performance with a correlation of 0.590 or has a moderate relationship with a contribution of $34.8 \%$. Hypothesis testing obtained $t$ count $>t$ table or $(5.322>2.006)$. Thus the second hypothesis proposed that there is a significant effect between motivation on employee performance is accepted.

\section{The Influence of Leadership and Motivation on Employee Performance}

Leadership and motivation have a significant effect on employee performance by obtaining a regression equation $\mathrm{Y}=10.742+0.439 \mathrm{X} 1+0.303 \mathrm{X} 2$, the correlation value of 0.753 , or has a strong relationship with the contribution of influence of $56.8 \%$ while the remaining $43.2 \%$ is influenced by other factors. Hypothesis testing obtained F count> F table or (34.149> 2.790). Thus the third hypothesis proposed that there is a significant effect between leadership and motivation on employee performance is accepted.

\section{CONCLUSION}

Leadership has a significant effect on employee performance with an influence contribution of $48.9 \%$. Hypothesis testing obtained $t$ count $>t$ table or (7.118> 2.006). Motivation has a significant effect on employee performance with an influence contribution of $34.8 \%$. Hypothesis testing obtained $t$ count $>t$ table or (5.322> 2.006). Leadership and motivation have a significant effect on employee performance with a contribution of $56.8 \%$ 
126 Jurnal Administrare: Jurnal Pemikiran Ilmiah dan Pendidikan Administrasi Perkantoran Vol. 7, No. 1, January - June 2020, Pages 119-128

while the remaining $43.2 \%$ is influenced by other factors. Hypothesis testing obtained the value of $F$ count $>F$ table or (34.149>2.790).

\section{REFERENCES}

Akdol, B., \& Arikboga, F. S. (2015). The Effects of Leader Behavior on Job Satisfaction: A Research on Technology Fast50 Turkey Companies. Procedia - Social and Behavioral Sciences, 195, 278-282. https://doi.org/https://doi.org/10.1016/j.sbspro.2015.06.159

Akib, H. (2008). Reaktualisasi fungsi dan peranan kepala sekolah. Jurnal Tenaga Kependidikan, $3(2)$.

Akib, H., \& Salam, R. (2016). Analisis Kualitas Pelayanan Publik Berbasis Importance Performance Analysis (IPA) pada Kecamatan Kota Makassar. Jurnal Ilmiah Scientific Pinisi.

Bircan, İ., \& Gençler, F. (2015). Analysis of Innovation-Based Human Resources for Sustainable Development. Procedia - Social and Behavioral Sciences, 195, 1348-1354. https://doi.org/https://doi.org/10.1016/j.sbspro.2015.06.321

Boer, J., \& Blaga, P. (2012). A More Efficient Production using Quality Tools and Human Resources Management. Procedia Economics and Finance, 3, 681-689. https://doi.org/https://doi.org/10.1016/S2212-5671(12)00214-6

Çetin, M., Karabay, M. E., \& Efe, M. N. (2012). The Effects of Leadership Styles and the Communication Competency of Bank Managers on the Employee's Job Satisfaction: The Case of Turkish Banks. Procedia - Social and Behavioral Sciences, 58, 227-235. https://doi.org/https://doi.org/10.1016/j.sbspro.2012.09.996

Córdova, F. M., Durán, C. A., Pincheira, M., Palominos, F., \& Galindo, R. (2019). Knowledge Management of Intangible Actives in Service Companies. Procedia Computer Science, 162, 596-603. https://doi.org/https://doi.org/10.1016/j.procs.2019.12.028

Cui, Y., Zhang, Y., Guo, J., Hu, H., \& Meng, H. (2019). Top management team knowledge heterogeneity, ownership structure and financial performance: Evidence from Chinese IT listed companies. Technological Forecasting and Social Change, 140, 14-21. https://doi.org/https://doi.org/10.1016/j.techfore.2018.12.008

Davila, A., \& Elvira, M. M. (2012). Humanistic leadership: Lessons from Latin America. $\begin{array}{llll}\text { Journal of } \quad \text { World } & \text { Business, }\end{array}$ https://doi.org/https://doi.org/10.1016/j.jwb.2012.01.008

Dumitriu, C., Timofti, I. C., Nechita, E., \& Dumitriu, G. (2014). The Influence of the Locus of Control and Decision-making Capacity upon the Leadership Style. Procedia - Social and Behavioral Sciences, 141, 494-499. https://doi.org/https://doi.org/10.1016/j.sbspro.2014.05.086

Edy, S. (2009). Manajemen Sumber Daya Manusia. Jakarta: Kencana. 
Gaines, L. K., \& Kappeler, V. E. (2011). 3 - Police Human Resources (L. K. Gaines \& V. E. B. T.-P. I. A. (Seventh E. Kappeler, ed.). https://doi.org/https://doi.org/10.1016/B978-1-43773488-1.00012-6

Huertas-Valdivia, I., Gallego-Burín, A. R., \& Lloréns-Montes, F. J. (2019). Effects of different leadership styles on hospitality workers. Tourism Management, 71, 402-420. https://doi.org/https://doi.org/10.1016/j.tourman.2018.10.027

Karatepe, O. M. (2013). High-performance work practices and hotel employee performance: The mediation of work engagement. International Journal of Hospitality Management, 32, 132-140. https://doi.org/https://doi.org/10.1016/j.ijhm.2012.05.003

Malik, N., Dhar, R. L., \& Handa, S. C. (2016). Authentic leadership and its impact on creativity of nursing staff: A cross sectional questionnaire survey of Indian nurses and their supervisors. International Journal of Nursing Studies, 63, 28-36. https://doi.org/https://doi.org/10.1016/j.ijnurstu.2016.08.004

Masini, E. B. (1990). Human Resources in Developing Countries. Futures, 22(10), 1037-1043. https://doi.org/https://doi.org/10.1016/0016-3287(90)90005-3

Moeheriono. (2018). Pengukuran Kinerja Berbasis Kompetensi.

Niswaty, R., Juniati, F., Darwis, M., Salam, R., \& Arhas, S. H. (2019). The Effectiveness of Leadership Functions Implementation in The Makassar Departement of Manpower. JPBM (Jurnal Pendidikan Bisnis dan Manajemen), 5(1), 1-10.

Sharafoddin, S., \& Emsia, E. (2016). The Effect of Stock Valuation on the Company's Management. Procedia Economics and Finance, 36, 128-136. https://doi.org/https://doi.org/10.1016/S2212-5671(16)30024-7

Sinambela, L. P. (2016). Manajemen Sumber Daya Manusia, Membangun Tim Kerja yang Solid untuk Meningkatkan Kinerja.

Spivack, A. J., \& Woodside, A. G. (2019). Applying Complexity Theory for Modeling Human Resource Outcomes: Antecedent Configurations Indicating Perceived Location Autonomy And Work Environment Choice. Journal of Business Research, 102, 109-119. https://doi.org/https://doi.org/10.1016/j.jbusres.2019.05.006

Suganthi, L. (2019). Examining the relationship between corporate social responsibility, performance, employees' pro-environmental behavior at work with green practices as mediator. Journal of Cleaner Production, 232, 739-750. https://doi.org/https://doi.org/10.1016/j.jclepro.2019.05.295

Sze, G., Bluth, E. I., Bender, C. E., \& Parikh, J. R. (2017). Work-Related Injuries of Radiologists and Possible Ergonomic Solutions: Recommendations From the ACR Commission on Human Resources. Journal of the American College of Radiology, 14(10), 1353-1358. https://doi.org/https://doi.org/10.1016/j.jacr.2017.06.021 
128 Jurnal Administrare: Jurnal Pemikiran Ilmiah dan Pendidikan Administrasi Perkantoran Vol. 7, No. 1, January - June 2020, Pages 119-128 